\title{
9. CALCAREOUS NANNOFOSSILS IN THE BASAL ZANCLEAN OF THE EASTERN MEDITERRANEAN SEA: REMARKS ON PALEOCEANOGRAPHY AND SAPROPEL FORMATION ${ }^{1}$
}

\author{
Davide Castradori ${ }^{2}$
}

\begin{abstract}
This paper presents the results of a study on nannofossil assemblages in the uppermost Messinian and basal Zanclean sediments recovered from Ocean Drilling Program (ODP) Holes 969B (south of Crete) and 967A (north of the Eratosthenes Seamount) located in the Eastern Mediterranean Sea. Focus of the research is on (1) the micropaleontological signature of the basically nonmarine facies of the uppermost Messinian interval; (2) the correlation of the Messinian/Zanclean boundary outside the Mediterranean by means of nannofossil biostratigraphy; and (3) the mechanism of sapropel formation in the earliest Pliocene. The main results are summarized as follows:

1. The Messinian sediments are characterized by assemblages dominated by diagenetic resistant and long-ranging Neogene species, absence of typical upper Tortonian-Messinian species, high abundance of reworked taxa of Cenozoic and Cretaceous age, and high abundance of gypsum crystals and dolomite. All evidence listed above point to the absence of a primary marine signature in the nannofossil assemblages of the sediments. A noticeable exception, constituted by anomalous abundance of Sphenolithus spp., which suggests a possible (marginal) marine signature, is documented.

2. The recovery of some specimens of Triquetrorhabdulus rugosus and of Ceratolithus acutus overlapping each other in the basal Zanclean suggests that, contrary to what has been reported by most authors, the last appearance datum (LAD) of $T$. rugosus and the first appearance datum (FAD) of $C$. acutus do not exactly coincide. This was already reported from the Ceara Rise (ODP Leg 154), where the FAD of $C$. acutus was found immediately below the cyclostratigraphically correlated position of the Messinian/Zanclean boundary. These closely spaced bioevents can be considered as a valuable tool, in addition to magnetostratigraphy and astrocyclostratigraphy, for the recognition and worldwide traceability of the Messinian/Zanclean boundary.

3. Based on a model by Molfino and McIntyre, fluctuation in abundance of Florisphaera profunda, a peculiar nannoplankton species living in the lower part of the photic zone, is interpreted to represent nutrient availability within different levels of the photic zone. Thus, positive peaks of $F$. profunda were connected by the author to the presence of a deep chlorophyll maximum (DCM) at times of sapropel formation, a concept previously introduced by Rohling and Gieskes for the mid-Pleistocene to Holocene time interval.

Abundance peaks of Florisphaera profunda are recorded in all five sapropel layers recovered in the basal Zanclean of ODP Hole 969B. Therefore, the DCM model may be tentatively applied also to the earliest Pliocene and probably to the whole sapropel sequence of the Mediterranean area, since the late Miocene.

The recovery of abundance peaks of Discoaster pentaradiatus in most sapropels (together with the decreased abundance of Coccolithus pelagicus in some of them), suggests that these sapropels probably correlate with the marls (and not the limestones) of the rhythmically bedded sedimentary sequences of the land sections in Sicily and Calabria (southern Italy), thus confirming previous assumptions by De Visser, Hilgen, and others.
\end{abstract}

\section{BACKGROUND AND OBJECTIVES}

This paper illustrates part of the results of a multidisciplinary study on the Messinian/Zanclean boundary based on data from four Ocean Drilling Program (ODP) sites, two from the Western Mediterranean (Leg 161, Sites 975 and 978) and two from the Eastern Mediterranean (Leg 160, Sites 967 and 969). The sites were selected to form a transect that may show different geographic, geologic, and paleoenvironmental settings.

The idea of a multidisciplinary stratigraphic research originated from the need to address, on a previously unavailable marine record, the problem of the restoration of open-marine conditions at the end of the Messinian salinity crisis. This event is of key importance from both paleoceanographic and chronostratigraphic points of view. Concerning the latter, the problem of the selection of an appropriate Global Standard Stratotype-section and Point (GSSP) of the Zanclean Stage strongly depends upon the demonstration of the absence of a significant hiatus across the Messinian/Zanclean boundary. This

${ }^{1}$ Robertson, A.H.F., Emeis, K.-C., Richter, C., and Camerlenghi, A. (Eds.), 1998. Proc. ODP, Sci. Results, 160: College Station, TX (Ocean Drilling Program).

${ }^{2}$ AGIP S.p.A., Laboratori Bolgiano, via Maritano 26, 20097 San Donato Milanese, Italy. davide.castradori@agip.it boundary was formally proposed in the Capo Rossello section by Cita (1975a) and subsequently proved to correlate with the fifth precession-related astronomical cycle below the Thvera magnetic event (Zijderveld et al., 1991; Hilgen, 1991b; Hilgen and Langereis, 1993). From a biostratigraphic point of view, the Messinian/Zanclean boundary is usually regarded as poorly constrained in the Mediterranean area, because of the basically nonmarine nature of the upper Messinian sediments (e.g., Arenazzolo Formation in Sicily) and of the lack of globally recognized nannofossil and foraminiferal bioevents in the very basal Zanclean. In particular, nannofossil species, such as Triquetrorhabdulus rugosus, Ceratolithus acutus, and $C$. rugosus, which define the zonal boundary of the oceanic standard zonation (Martini, 1971; Okada and Bukry, 1980), are rare in the Mediterranean stratigraphic record.

The discussion in the scientific community about the Messinian/ Zanclean boundary is really animated (see Berggren et al., 1995b, for a review). To summarize, there are three possible options for the formalization of a GSSP of the Zanclean Stage (as base of the Pliocene Series): (1) the base of the Trubi in the Capo Rossello area; (2) an appropriate level in an extra-Mediterranean section selected to correspond to the base of the Trubi (counting five precession-related cycles below the Thvera magnetic event); (3) an appropriate level in an extra-Mediterranean section selected to correspond approximately to the base of the Gilbert epoch (Benson and Hodell, 1994), thus decou-

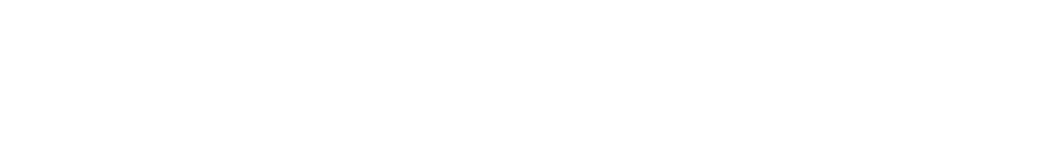


pling the Messinian/Zanclean stage boundary from the Miocene/ Pliocene series boundary (see discussions in Berggren et al., 1995a, 1995b).

Whatever option will be preferred by the International Commission on Stratigraphy (ICS) (and ratified by the International Union of Geological Sciences), the position of the Messinian/Zanclean boundary in the Mediterranean with respect to biohorizons recognized in the world oceans is relevant to the solution of the problem. This paper presents some information on this matter, together with quantitative and semiquantitative data on nannofossil assemblages that characterize the sapropel layers intercalated in the basal Zanclean of Sections 160-969B-11H-5 and 6.

The origin of sapropels is another problem that gave rise to many different genetic theories in the last decades (see Rohling, 1994, for an overview). In synthesis, sapropels, which are organic matter-rich, dark-colored pelagic layers interbedded in the land and marine Mediterranean record since middle Miocene times (and particularly in the Pliocene and Pleistocene; Kidd et al., 1978), may have originated from increased primary production in the photic zone (e.g., Calvert, 1983; Sutherland et al., 1984; Pedersen and Calvert, 1990; Calvert et al., 1992), from anoxia in the bottom waters (e.g., Olausson, 1961, Ryan, 1972; Thunell, 1979; Thunell and Williams, 1983; Thunell et al., 1977; Cita et al, 1977; Muerdter, 1984), or from a complex interplay of the two (e.g., Rohling and Gieskes, 1989; Rohling, 1991; Rohling and Hilgen, 1991; Castradori, 1993; Rohling, 1994).

Even if anoxia of the bottom waters was the primary mechanism, it was probably triggered by decreased salinity of the surficial waters that are, therefore, the environment where the entire process originated. That is why studies of planktonic microfossils living in the upper part of the water column may play a critical role for unraveling the whole story. Since the 1960's, the assemblage composition and isotopic signature of planktonic foraminifers have been investigated in detail, initially in mid-Pleistocene to Holocene sapropels (e.g., Olausson, 1961; Cita et al., 1977, Rohling and Gieskes, 1989), then in those of mid-Pliocene to Pleistocene age that outcrop on land (particularly in southern Italy; e.g., Lourens et al., 1992), and lastly in upper Miocene sapropels of Crete (Nijenhuis et al., 1996).

Recently, calcareous nannofossils (the fossil calcareous cover of planktonic algae) have also been studied to decipher the formation mechanisms of mid-Pleistocene to Holocene sapropels (Castradori, 1993). This study highlighted increased abundance of Florisphaera profunda (the only species of calcareous nannoplankton that inhabits the lower part of the photic zone) in most sapropel layers, with respect to the underlying and overlying normal pelagic marls. Based on a study by Molfino and McIntyre (1990a, 1990b) that demonstrated a clear link between the abundance variations of $F$. profunda and the nutrient availability at different depths of the photic zone, it was proposed that the increased abundances of $F$. profunda in the sapropel layers witnessed the presence of a Deep Chlorophyll Maximum (DCM). The presence of a distinct DCM at times of sapropel formation was initially hypothesized by Rohling and Gieskes (1989), mainly on the evidence of increased abundance of neogloboquadrinids. The increased primary production in a DCM was then considered as the triggering mechanism for the formation of most sapropel layers of mid-Pleistocene to Holocene age (Rohling and Gieskes, 1989; Castradori, 1993), although anoxia may have played a key role, particularly for the formation of those sapropels with a relatively lower organic carbon content (Rohling, 1994). A similar scenario has been hypothesized also for the formation of late Pliocene and early Pleistocene sapropels (Lourens et al., 1992) and, recently, for the late Miocene sapropelites that outcrop on Crete (Nijenhuis et al., 1996).

In this paper, I will try to prove or disprove whether the DCM model may be applied also to the formation of earliest Pliocene sapropels. To do so, the abundance variations of $F$. profunda will be analyzed across five sapropel layers. In addition, the abundance fluctuations of different Discoaster species, a group with peculiar paleoecological preferences extinct since the late Pliocene (e.g., Backman and Pestiaux, 1987; Chepstow-Lusty et al., 1989), will provide additional information on the paleoenvironmental conditions at times of sapropel formation.

\section{MATERIAL AND METHODS}

Site 969 is located on the Mediterranean Ridge, some $100 \mathrm{~km}$ south of Crete, at a water depth of about $2200 \mathrm{~m}$ (Fig. 1). The location was selected to recover a sedimentary record of sapropel formation on the ridge that separates the Ionian (to the west) and the Levantin (to the east) basins. A secondary goal was the recovery of a welldeveloped Messinian-Zanclean sequence to address the problem of the restoration of open-marine conditions following the Mediterranean "salinity crisis" (Emeis, Robertson, Richter, et al., 1996).

Site 967 is located on the northern slope of the Eratosthenes Seamount, at a water depth of $2552 \mathrm{~m}$, in a position critical for testing the hypothesis of tectonic underthrusting of the Seamount beneath the island of Cyprus (Fig.1). Subsidiary goals of Site 967 were the reconstruction of paleoenvironments at the Messinian/Zanclean boundary and the recovery of a Pliocene/Pleistocene succession more expanded and better resolved with respect to that of Site 966, which is located on top of the Eratosthenes at a much shallower depth (Emeis, Robertson, Richter, et al., 1996).

Sampling for this study was limited to the uppermost meters of Messinian sediments and to the lowermost meters of the basal Zanclean. Twenty-four samples were collected from Sections 160-969B$11 \mathrm{H}-5$ through $11 \mathrm{H}-7$, and 22 samples from Sections 160-967A$14 \mathrm{X}-1$ through $13 \mathrm{H}-1$. In particular, sampling of the basal Zanclean at Hole 969B was focused on the alternation of sapropels and normal pelagic marls to obtain a preliminary picture of their peculiar nannofossil assemblages. In contrast, the absence of sapropel layers in the basal Zanclean of Site 967 suggested a more regular sampling interval (2-3 samples per section) throughout foraminifer Zones MPI 1 and basal MPI 2 (Cita, 1975b).

For each sample, a smear slide was prepared and analyzed with an optical microscope at $1000 \times$. However, Discoaster abundances were determined at $630 \times$ magnification. No special technique was applied to clean or concentrate the biogenic fraction to retain the original composition of the nannofossil assemblages.

Distribution of calcareous nannofossils in the basal Pliocene of the Mediterranean area is rather poorly known, possibly because of the local scarcity of oceanic marker species (see above). Therefore, a semiquantitative description of the whole nannofloral assemblage

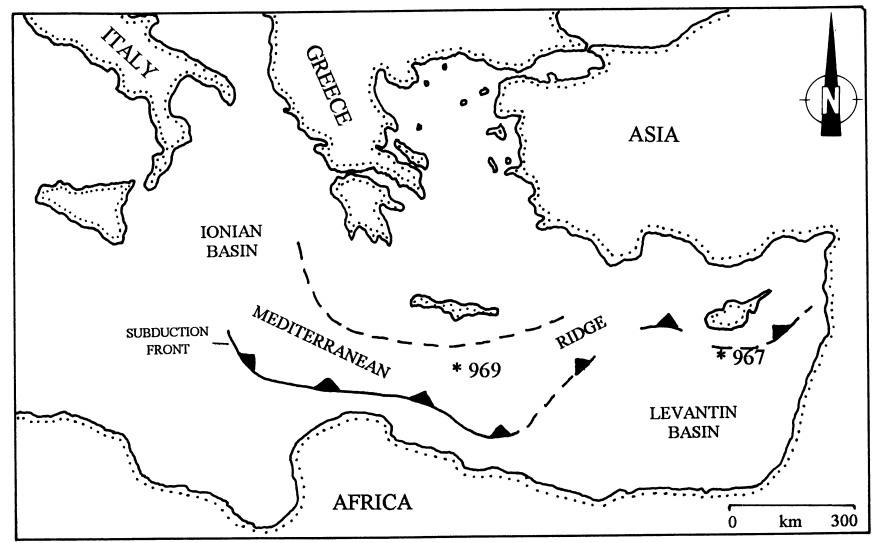

Figure 1. Location map of the two sites studied. Site 969 is located on the Mediterranean Ridge (at a water depth of $2200 \mathrm{~m}$ ) on a topographic high that separates the Ionian (to the west) and the Levantin (to the east) basins. Site 967 is located on the northern slope of the Eratosthenes Seamount (at a water depth of $2552 \mathrm{~m}$ ), just to the south of the inferred subduction front. 
was considered suitable. Results are reported in Tables 1 and 2 (including a visual evaluation of presence and relative abundance of mineral components, such as gypsum and dolomite). The total abundance of nannofossils is recorded as abundant $(\mathrm{A}=$ more than 30 specimens/1 field of view), common ( $\mathrm{C}=10-30$ specimens $/ 1$ field of view), or scarce ( $\mathrm{S}=1-10$ specimens/1 field of view) and the overall preservation is qualitatively classified as good $(\mathrm{G})$, moderate $(\mathrm{M})$, or poor $(\mathrm{P})$. Semiquantitative abundance of single species is reported according to the following classes:

$A=$ abundant (more than 10 specimens per field of view);

$\mathrm{C}=$ common $(1-10$ specimens per field of view);

$\mathrm{S}=$ scarce $(1$ specimen every $1-10$ fields of view);

$\mathrm{R}=$ rare (1 specimen in more than 10 fields of view); and

$\mathrm{RR}=$ very rare $(1$ specimen in standard analysis $)$.

In addition, a quantitative analysis was performed on the Discoaster and Amaurolithus groups and on Florisphaera profunda. Discoaster and Amaurolithus were counted on a fixed area of each slide (10 $\mathrm{mm}^{2}$; Backman and Shackleton, 1983; Rio et al., 1990). In Tables 1 and 2, the abundance of single species of Discoaster and Amaurolithus is reported as number of specimens $/ \mathrm{mm}^{2}$, whereas in Figures 2 and 3, percentage values of each species with respect to the entire group are reported to avoid discrepancies caused by the different quantity of sediment smeared onto a slide.

The variations in abundance of $F$. profunda were recorded on what is probably more a semiquantitative than a truly quantitative basis. Following Castradori (1993) and also partially Matsuoka and Okada (1989), the abundance of this species in a given sample is computed as number of its specimens compared to 100 specimens of all other species. This counting procedure is justified by the peculiar morphologic features of $F$. profunda (thin, gray, small calcite plates of polygonal shape; Pl. 2, Fig. 1) and by its unique habitat, the lower part of the photic zone (compared to the middle and upper parts where all the other species live).

\section{RESULTS AND DISCUSSION}

In this section, the analytical data (Tables 1, 2; Figs. 2, 3) will be presented and discussed according to their relevance for: (1) paleontological and sedimentological characteristics of the uppermost Messinian; (2) biostratigraphy and chronostratigraphy of the Messinian/Zanclean boundary; and (3) paleoceanography and mechanism of sapropel formation in the basal Zanclean.

\section{Paleontological and Sedimentological Characteristics of the Uppermost Messinian}

The stratigraphic intervals from Samples 160-969B-11H-7, 40$42 \mathrm{~cm}$, to $11 \mathrm{H}-6,128-129 \mathrm{~cm}$, and from Samples 160-967A-14X-1, $119-122 \mathrm{~cm}$, to $13 \mathrm{H}-4,78-80 \mathrm{~cm}$, are assigned to the Messinian on the basis of sedimentological features (Emeis, Robertson, Richter, et al., 1996), characteristics of the fossil assemblages (discussed in this section), and biostratigraphic signature of the overlying marine Zanclean (see below).

With the exception of Samples 160-967A-13H-6, 79-81 cm, and $13 \mathrm{H}-6,99-101 \mathrm{~cm}$, which were prepared from Zanclean sediments that had been mechanically intruded into the Messinian sequence by drilling disturbances, the samples analyzed from the Messinian interval are characterized by the following (also see Tables 1,2):

1. Relatively high abundance of calcareous nannofossils, with moderate to poor preservation;

2. Assemblages dominated by diagenetic resistant and long-ranging Neogene species, such as Reticulofenestra pseudoumbili- cus, small Reticulofenestra, Dictyococcites spp., Coccolithus pelagicus, Sphenolithus moriformis;

3. Absence of typical upper Tortonian-Messinian species (e.g., Discoaster quinqueramus, Discoaster berggrenii, Amaurolithus spp.);

4. High abundance of reworked taxa of Cenozoic and Cretaceous age; and

5. High abundance of gypsum crystals (often twin crystals, Pl. 1, Figs. 1-4) and dolomite.

All the evidence listed above point to the absence of a primary marine signature in the Messinian sediments investigated. Samples $160-967 \mathrm{~A}-14 \mathrm{X}-1,54-57 \mathrm{~cm}$, and $14 \mathrm{X}-1,72-75 \mathrm{~cm}$ are characterized, however, by an anomalous abundance of Sphenolithus spp. (mostly Sphenolithus gr abies/moriformis; Pl. 1, Fig. 6). Such a peculiar feature, noted also in some samples from the uppermost Messinian of the western Mediterranean ODP Sites 975 and 978 (D. Castradori, unpubl. data), cannot be explained if reworking was responsible for the observed assemblages. This anomalous signature may witness the existence of temporary (marginal) marine settings predating the Zanclean ingression. This is obviously a preliminary interpretation that needs further investigation.

Samples 160-969B-11H-6, 124-126 cm, and 160-967A-13H-4, 25-27 cm, bear the first evidence of primary marine assemblages of Zanclean age. Assemblages are characterized by very abundant calcareous nannofossils with moderate to good preservation. The abundance of reworked taxa, gypsum crystals, and dolomite clearly decreases upward, although they may be rather abundant in some layers.

\section{Biostratigraphy and Chronostratigraphy of the Messinian/Zanclean Boundary}

The Messinian/Zanclean boundary, as defined at the base of the Trubi Formation in Sicily, can now be correlated outside the Mediterranean on the basis of magnetostratigraphy and astrocyclostratigraphy (counting five precession-related cycles below the base of the Thvera magnetic event; see above). In most biostratigraphic schemes, the Messinian/Zanclean boundary is bracketed by the last appearance datum (LAD) of Discoaster quinqueramus (below) and the LAD of Triquetrorhabdulus rugosus and first appearance datum (FAD) of Ceratolithus acutus (above) (Berggren et al., 1995a, 1995b; Raffi and Flores, 1995). Therefore, in terms of the nannofossil zonation of Okada and Bukry (1980), the Messinian/Zanclean boundary in the ocean domain is usually correlated to Subzone 10a.

Very recently, Backman and Raffi (1997) documented, from the Ceara Rise, that $C$. acutus actually appears before the extinction level of $T$. rugosus. The astrocyclostratigraphic calibration of the LAD of D. quinqueramus (5.537 Ma), FAD of C. acutus (5.372 Ma), and LAD of T. rugosus (5.231 Ma), obtained by Backman and Raffi (1997), clearly demonstrates that the Messinian/Zanclean boundary (5.32 Ma) is very well constrained outside the Mediterranean, on the basis of nannofossil biostratigraphy.

In the Mediterranean, the LAD of D. quinqueramus is not documented because of the essentially nonmarine character of the deposits of that time interval (upper Messinian evaporitic and postevaporitic interval). The last specimens of T. rugosus and the first specimens of C. acutus should in principle be detectable in the first meters of the Zanclean Stage. Unfortunately, the record of both species is very scattered, and they are seldom reported in the literature. In particular, Gartner (in Cita and Gartner, 1973) reported C. acutus in the basal Zanclean of the Capo Rossello section, starting from $6 \mathrm{~m}$ above the Messinian/Zanclean boundary, whereas he did not mention the presence of $T$. rugosus. On the contrary, Rio et al. (1984) found a few $T$. rugosus in the first $6 \mathrm{~m}$ of the basal Zanclean (again in the Capo Rossello section), but they did not find any $C$. acutus. 
Table 1. Calcareous nannofossil distribution chart of the uppermost Messinian and basal Zanclean in Hole 969B.

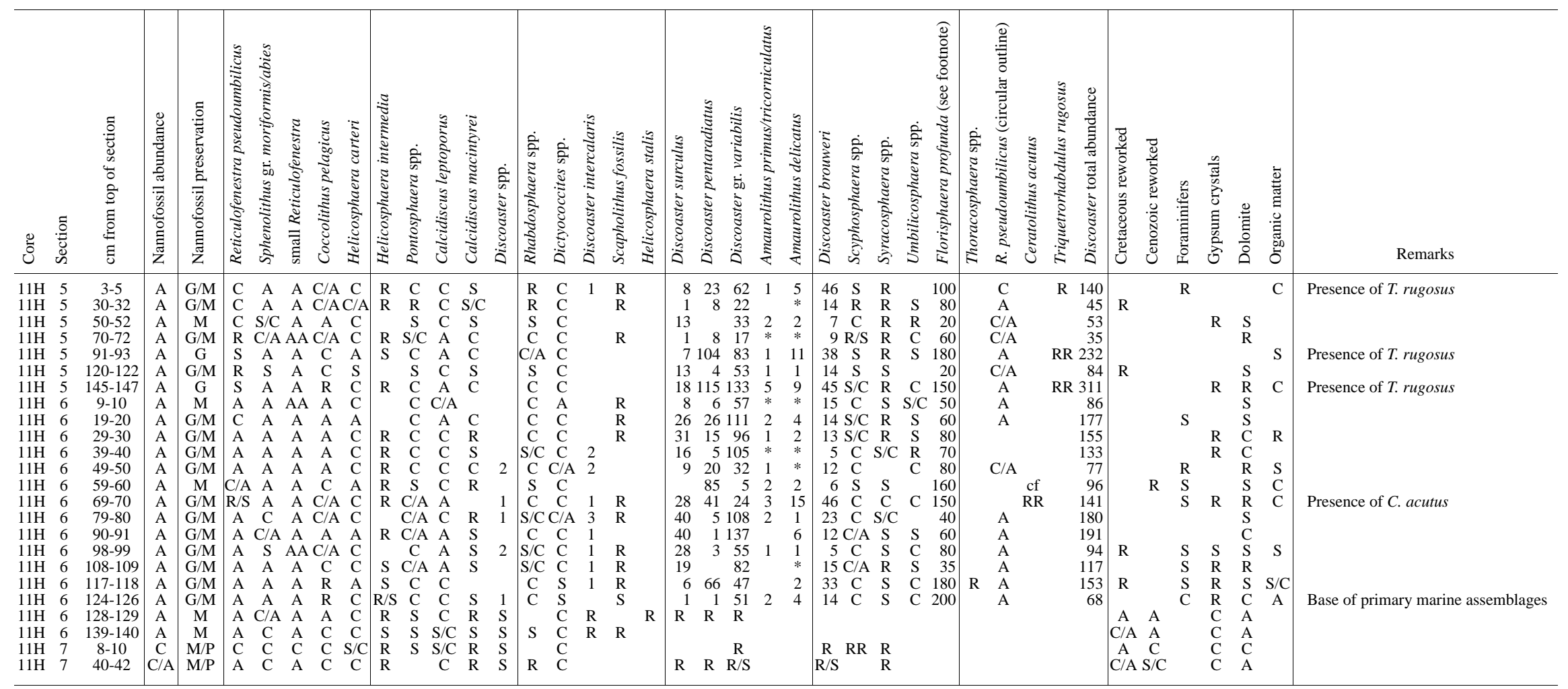

Notes: $*$ detected only in extra analysis. Relative abundances are semiquantitative when in letters (see "Material and Methods" section [this chapter] for abundance keys) and quantitative when in numbers (number of specimens/mm²). Abundance of $F$. profunda is related to 100 specimens of all other species (see "Material and Methods" section [this chapter]). Abundance of gypsum crystals and dolomite are purely qualitative. 
Table 2. Calcareous nannofossil distribution chart of the uppermost Messinian and basal Zanclean in Hole 967A.

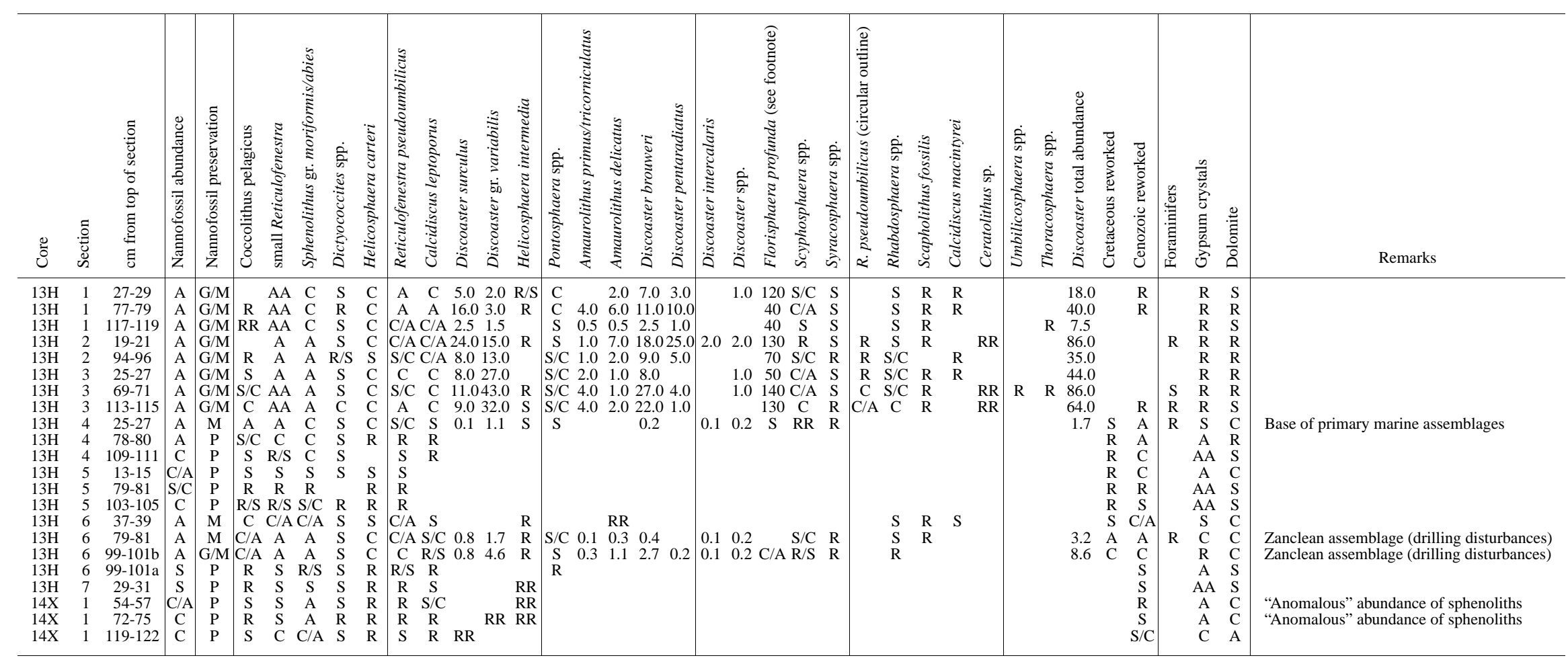

Notes: Relative abundances are semiquantitative when in letters (see "Material and Methods" section [this chapter] for abundance keys) and quantitative when in numbers (number of specimens/mm2). Abundance of $F$. profunda is related to 100 specimens of all other species (see "Material and Methods" section [this chapter]). Abundance of gypsum crystals and dolomite are purely qualitative estimates. 


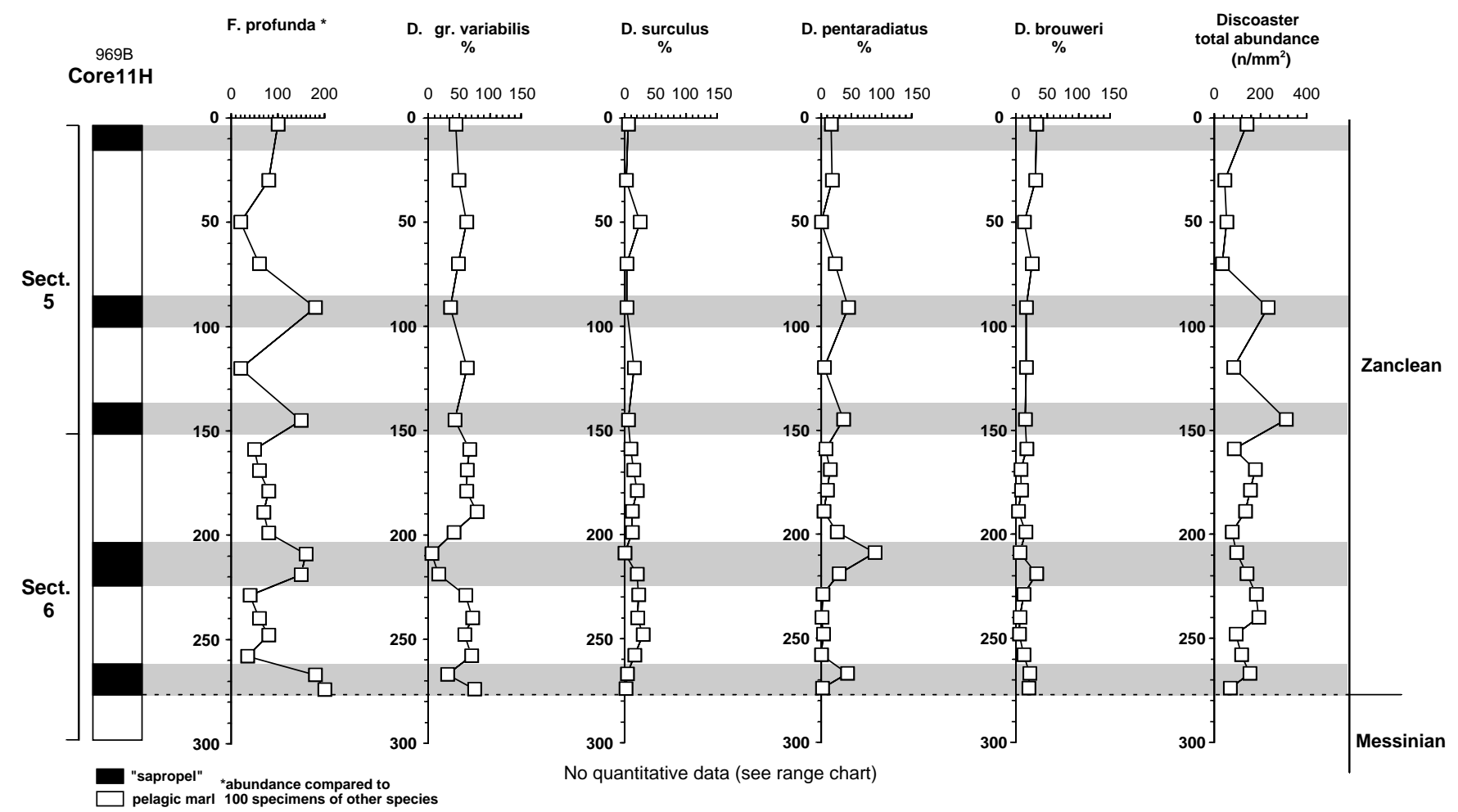

Figure 2. Quantitative abundance pattern of selected nannofossil species in the basal Zanclean of Hole 969B. For explanation on analytical methods, see the "Material and Methods" section (this chapter).

In this study, I found a few very well-preserved specimens of $T$. rugosus (Pl. 1, Fig. 7) up to the topmost part of Section 160-969B$11 \mathrm{H}-5$ (last sample studied). Moreover, two specimens of $C$. acutus (Pl. 1, Fig. 5) were found in Samples 160-969B-11H-6, 69-70 cm, and $11 \mathrm{H}-6,59-60 \mathrm{~cm}$. Specimens of Ceratolithus sp. (probably $C$. acutus) were also detected at Sections 160-967A-13H-2 and 13H-3 (see Table 2). I did not observe specimens of D. quinqueramus in any of the analyzed samples.

My biostratigraphic findings indicate that:

1. Contrary to what reported by Bukry (1973), Okada and Bukry (1980), and Berggren et al. (1995a, 1995b) the LAD of T. rugosus and the FAD of C. acutus do not exactly coincide, a detectable overlap being present in the basal Zanclean. This is in good agreement with what reported by Backman and Raffi (1997) from the Ceara Rise.

2. The FAD of $C$. acutus is probably the best approximation of the Messinian/Zanclean boundary, in terms of nannofossil biostratigraphy.

Other data obtained in the present study seem promising from biostratigraphic and chronostratigraphic points of view. In particular, the presence of rather numerous specimens of Helicosphaera intermedia (in samples with virtually no reworking) in the basal Zanclean of Holes 969B and 967A is rather surprising (Pl. 2, Fig. 5). As far as I know, this typical Miocene species has never been reported in the basal Pliocene. I suggest to investigate further the upper part of the stratigraphic range of $H$. intermedia, whose LAD may prove useful as a subsidiary tool for the identification of the basal Zanclean.

Another unusual morphotype is a Reticulofenestra sp. with circular outline and overall dimensions of $\sim 6-8 \mu \mathrm{m}$ (Pl. 2, Fig. 2). This morphotype is abundant throughout Sections 160-969B-11H-5 and $11 \mathrm{H}-6$ and in Sections 160-967A-13H-2 through 13H-4. I was not able to find reports of this species in the literature. This may mean that its stratigraphic range is restricted to the basal Zanclean, but it obviously needs further investigation.

\section{Paleoceanography and Mechanism of Sapropel Formation}

The following focuses on sediments from Hole 969B in which five sapropel layers were recovered in the basal Zanclean. There were no sapropel layers recovered from this stratigraphic interval in Hole 967A.

\section{Florisphaera profunda}

Table 1 and Figure 2 show the abundance of $F$. profunda in the basal Zanclean of Hole 969B. It is clearly evident that this species has an abundance pattern strictly linked to the sapropel/nonsapropel pattern. In fact, abundance peaks of $F$. profunda are present in all sapropel layers, and particularly in the lower four (Pl. 2, Fig. 1). It should be emphasized that nannofossil assemblages within sapropels are usually well preserved, often better than the normal underlying and overlying pelagic marls (see also Müller, 1978, 1985; Violanti et al., 1991; Castradori, 1993). Therefore, I consider the quantitative pattern of $F$. profunda detected in these sediments as a genuine product of abundance variations in the primary nannoplankton population. F. profunda shows some abundance fluctuations also in sediments from Hole 967A (Table 2; Fig. 3) that are not directly related to any peculiar sedimentological features.

\section{Discoaster and Amaurolithus}

Abundance variations of the Discoaster and Amaurolithus groups, as well as of their different species, are reported in Tables 1 and 2 and Figures 2 and 3. 


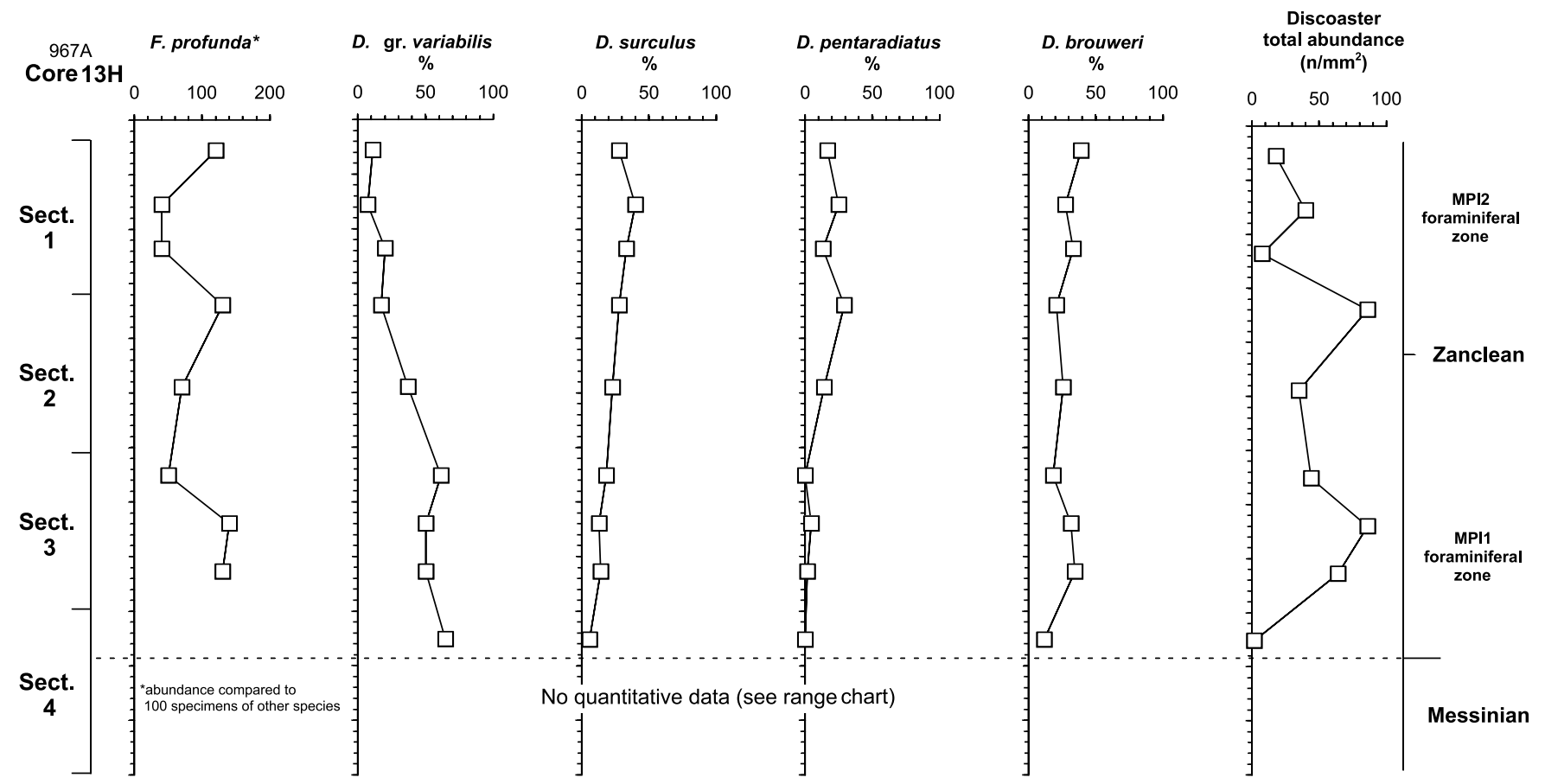

Figure 3. Quantitative abundance pattern of selected nannofossil species in the basal Zanclean of Hole 967A. For explanation on analytical methods, see the "Material and Methods" section (this chapter).

Discoaster spp. are present in very high abundances (up to 300 , and usually $>100$ specimens $/ \mathrm{mm}^{2}$ ), especially when compared to corresponding values obtained in the Western Mediterranean (our data, ODP Sites 975 and 978) and in the Tyrrhenian Sea (Rio et al., 1990).

Generally speaking, Discoaster variabilis is the most abundant species throughout. Discoaster pentaradiatus, D. surculus, and D. brouweri are often well represented, the latter two particularly in sediments from Hole 967A.

In sediments from Hole 969B, there seems to be a connection between increased total Discoaster abundance and the sapropel layers, particularly the lower two sapropels of Section 160-969B-11H-5. Probably more obvious is the presence of abundance peaks of $D$. pentaradiatus within the two sapropels of Section 160-969B-11H-6 and in the lower two of Section 160-969B-11H-5. D. variabilis shows negative excursions in the same layers, both as "absolute" number per $\mathrm{mm}^{2}$ (Table 1) and as a percentage of the Discoaster assemblage (Fig. 2).

With abundance values up to 18 specimens $/ \mathrm{mm}^{2}$, Amaurolithus spp. are much more abundant than in corresponding intervals of the Tyrrhenian Sea (Rio et al., 1990) and of the Western Mediterranean (our data, ODP Sites 975 and 978). No straightforward relationship is noted between abundance variations of this group and the sapropel pattern.

\section{Scyphosphaera spp.}

Tables 1 and 2 record the semiquantitative abundance variations of this taxonomic group (Pl. 2, Figs. 3-4 and 6-7). It can be noted that Scyphosphaera spp. are always well represented, and often abundant, in the Zanclean sediments. Relative abundance of this group was also noted in ODP Site 132 (Raffi and Rio, 1979), whereas it has sporadic occurrences in the basal Zanclean of the Capo Rossello section (Rio et al., 1984). No easily discernible relation is observed between the abundance variations and the sapropel/nonsapropel pattern.

\section{Coccolithus pelagicus}

On a semiquantitative basis, the abundance variations of this species show distinctive features. First of all, this species seems generally less abundant in the Eastern than in the Western Mediterranean (Müller, 1985; our data, ODP Sites 975 and 978). Moreover, intervals of remarkably low abundances are recorded. In sediments from Hole 969B, two intervals of strongly decreased abundance coincides with the lower sapropel of Section 6 and with the lower sapropel of Section 5. In Hole 967A, an interval of almost complete absence of $C$. pelagicus was detected from Samples 160-967A-13H-2, 94-96 cm, up to $13 \mathrm{H}-1,27-29 \mathrm{~cm}$ (uppermost sample studied).

\section{Summary}

The analytical results outlined above provide important insights on the mechanism of sapropel formation. The only species that shows an abundance pattern clearly related to the sapropel pattern is $F$. profunda. In addition, D. pentaradiatus and $C$. pelagicus seem partially sensitive to the mechanism of sapropel formation.

The abundance peaks of $F$. profunda suggest a genetic relationship between the basal Zanclean sapropels and those of mid-Pleistocene to Holocene age (Castradori, 1993). In both cases, the increased abundance of $F$. profunda is interpreted as a result of the presence of a DCM, that is of enhanced primary production in the lower part of the photic zone. The DCM forms as a result of decreased salinity of surficial waters in the source area of the Mediterranean Intermediate Water (MIW), near Turkey (Rohling and Gieskes, 1989). This reduced salinity is caused by higher than normal runoff of the Nile River (Rossignol-Strick, 1985) and enhanced precipitation over the land bordering the Levantine Basin to the east (Rohling and Hilgen, 1991) at times of increased seasonality in the Northern Hemisphere (i.e., perihelion in the boreal summer; see Rohling, 1994, for a review). This reduced salinity would cause a shoaling (up to the lower part of the photic zone) of the pycnocline 
separating the MIW from the overlying surficial waters. This rising determines the upward mixing of new nutrients into the lower photic zone (where $F$. profunda lives), with the development and maintenance of a DCM. In such a setting, primary production is mainly "new" production, which greatly increases the export of organic matter from the photic zone (e.g., Legendre and Le Fevre, 1989; Eppley, 1989 ). Therefore, the abundance of $F$. profunda is a proxy for the increased export of organic matter from the photic zone.

From studying calcareous nannofossils that live in the upper part of the water column, no conclusion can be reached about the development of anoxia in the bottom waters. In my opinion, anoxia, considered the primary mechanism of sapropel formation by many authors (see "Background and Objectives"), may have played an important role, in particular for the formation of those sapropels with a not so high organic carbon content (according to Rohling, 1994). However, the abundance variations of $F$. profunda demonstrate that increased primary production is an important factor, and probably the triggering mechanism, for the formation of (most) sapropel layers.

The abundance pattern of the Discoaster group and of Coccolithus pelagicus suggests an interesting relationship between the sapropel/nonsapropel pattern in the basal Zanclean of ODP Hole 969B and the limestone-marl couplets that characterize the time equivalent Trubi Formation widely outcropping in Sicily and Calabria (Southern Italy).

The couplets of the Trubi Formation are unanimously thought to reflect the periodicity of the Earth precession cycle ( 21-23 k.y.) (e.g., Hilgen, 1991a, 1991b; Thunell et al., 1991a, 1991b). However, the mechanism through which the astronomical signal is transferred into the sedimentary record is far from clear.

According to De Visser et al. (1989), the marl is the product of higher fertility and temperature of the surficial waters (witnessed by increased abundance of Neogloboquadrina acostaensis, lower $\delta^{18} \mathrm{O}$, and higher Barium content) at times of increased runoff. The marls were considered by these authors as the "equivalent" of the sapropels characterizing the Monte Narbone Formation, overlying the Trubi in Sicily and Calabria (see also Lourens et al., 1996). On this assumption, Hilgen (1991a, 1991b) proposed his astronomically calibrated time scale, where marl layers (in the Trubi) and sapropels (in the Monte Narbone) are correlated with periods of increased seasonality in the Northern Hemisphere (perihelion in the boreal summer at times of maximum eccentricity).

On the contrary, Thunell et al. (1991a, 1991b) interpreted the limestones (and not the marls) as the result of increased primary production connected with localized upwelling phenomena in the Mediterranean region. They indicated the abundance of Globigerina bulloides, benthic foraminifers, Coccolithus pelagicus (indicating cold upwelled waters), and small placoliths as the results of the increased primary production in the limestones, whereas abundant Globigerinoides spp. and Discoaster spp. (particularly D. pentaradiatus) and scarcity of benthic foraminifers would be the result of warm water and lower productivity.

The analytical results of the present study, that is, increased abundance of D. pentaradiatus (and probably of the Discoaster as a group) in most sapropels and decreased abundance of $C$. pelagicus in two of them, indicate, when compared with data of Thunell et al. (1991a, 1991b), that the sapropels recovered in Hole 969B are probably to be correlated to the marly layers of the Trubi Formation, in agreement with the interpretation by De Visser et al. (1989), Hilgen (1991a, 1991b), and Lourens et al. (1996). This conclusion comes from a simple comparison of analytical data from the different lithologies studied.

In our model of sapropel formation (Rohling and Gieskes, 1989; Castradori, 1993; this paper), the relatively higher abundance of Discoaster, and particularly $D$. pentaradiatus, in the sapropel layers may indicate either an increased temperature of the surficial waters (the
Discoaster group, and particularly D. pentaradiatus, showing warmwater preferences; Backman and Pestiaux, 1987, Thunell et al., 1991a) or a low primary production in the upper part of the photic zone (the Discoaster as a group being an indicator of oligotrophic conditions; Chepstow-Lusty et al., 1989), or even both conditions. In fact, in the DCM model, the increased primary production is confined to the lower part of the photic zone, whereas the upper layers may be characterized by relatively low primary production and may be also by higher temperatures (at least in summer). The latter would be responsible for the observed decreased abundances of $C$. pelagicus, this species being a well-known cold-water indicator (e.g., McIntyre and Bé, 1967; McIntyre et al., 1970; Geitzenauer et al., 1976).

The relatively high abundances of Scyphosphaera spp. recorded in the present study and in the Western Mediterranean (Raffi and Rio, 1979; our data, ODP Sites 975 and 978) are of problematic interpretation. Unfortunately, the paleoecology of this group is largely unknown. However, it seems to show a preference for neritic, nearshore environments (Perch-Nielsen, 1985).

Very preliminarily, it may be suggested that the high abundance of this group may have originated during the earliest times of the Zanclean transgression, when the basically nonmarine environments characterizing most of the Mediterranean area were rapidly transgressed by the incoming waters, which gave rise for a while to widely distributed neritic environments. Then, scyphosphaerids may have proliferated, at least for a short time interval, in the overlying openmarine sediments.

\section{CONCLUDING REMARKS}

The analytical data presented here allowed me to characterize the uppermost Messinian sediments and provide some constraints on the correlation of the Messinian/Zanclean boundary outside the Mediterranean by means of calcareous nannofossils.

The more interesting outcome of this paper is probably the possibility to apply the DCM model of sapropel formation to the basal Zanclean. In this scenario, enhanced export of organic matter toward the seafloor results from an increased primary production in the lower part of the photic zone (DCM). As for mid-Pleistocene to Holocene sapropels (Castradori, 1993), the abundance variations of $F$. profun$d a$ are of key importance, even in the basal Zanclean, as a proxy of a similar scenario. Since the DCM model has been applied also to the formation of late Pliocene and early Pleistocene sapropels (Lourens et al., 1992) and, very recently, of late Miocene sapropelites outcropping on Crete (Nijenhuis et al., 1996), it appears that the same mechanism may have triggered the formation of most sapropel layers in the sedimentary record of the Mediterranean area.

\section{ACKNOWLEDGMENTS}

My sincere thanks are due to Maria Bianca Cita for her always encouraging and supportive attitude; to Kay Emeis and Angelo Camerlenghi for useful advice; to Wuchang Wei, Carl Richter, and an anonymous reviewer for helpful comments; to Stefano Torricelli for technical help; and to Renata and Luca, for their patience.

\section{REFERENCES}

Backman, J., and Pestiaux, P., 1987. Pliocene Discoaster abundance variations, Deep Sea Drilling Project Site 606: biochronology and paleoenvironmental implications. In Ruddiman, W.F., Kidd, R.B., Thomas, E., et al., Init. Repts. DSDP, 94 (Pt. 2): Washington (U.S. Govt. Printing Office), 903-910.

Backman, J., and Raffi, I., 1997. Calibration of Miocene nannofossil events to orbitally tuned cyclostratigraphies from Ceara Rise. In Shackleton, 
N.J., Curry, W.B., Richter, C., and Bralower, T.J. (Eds.), Proc. ODP, Sci Results, 154: College Station, TX (Ocean Drilling Program), 83-99.

Backman, J., and Shackleton, N.J., 1983. Quantitative biochronology of Pliocene and early Pleistocene calcareous nannofossils from the Atlantic, Indian and Pacific oceans. Mar. Micropaleontol., 8:141-170.

Benson, R.H., and Hodell, D.A., 1994. Comment on "A critical re-evaluation of the Miocene/Pliocene boundary as defined in the Mediterranean" by F.J. Hilgen and C.G. Langereis. Earth Planet. Sci. Lett., 124:245-250.

Berggren, W.A., Hilgen, F.J., Langereis, C.G., Kent, D.V., Obradovich, J.D., Raffi, I., Raymo, M.E., and Shackleton, N.J., 1995a. Late Neogene chronology: new perspectives in high-resolution stratigraphy. Geol. Soc. Am. Bull., 107:1272-1287.

Berggren, W.A., Kent, D.V., Swisher, C.C., III, and Aubry, M.-P., 1995b. A revised Cenozoic geochronology and chronostratigraphy. In Berggren, W.A., Kent, D.V., Aubry, M.-P., and Hardenbol, J. (Eds.), Geochronology, Time Scales and Global Stratigraphic Correlation. Spec. Publ.Soc. Econ. Paleontol. Mineral., 54:129-212.

Bukry, D., 1973. Low-latitude coccolith biostratigraphic zonation. In Edgar, N.T., Saunders, J.B., et al., Init. Repts. DSDP, 15: Washington (U.S. Govt. Printing Office), 685-703.

Calvert, S.E., 1983. Geochemistry of Pleistocene sapropels and associated sediments from the Eastern Mediterranean. Oceanol. Acta, 6:255-267.

Calvert, S.E., Nielsen, B., and Fontugne, M.R., 1992. Evidence from nitrogen isotope ratios for enhanced productivity during the formation of eastern Mediterranean sapropels. Nature, 359:223-225.

Castradori, D., 1993. Calcareous nannofossils and the origin of eastern Mediterranean sapropels. Paleoceanography, 8:459-471.

Chepstow-Lusty, A., Backman, J., and Shackleton, N.J., 1989. Comparison of upper Pliocene Discoaster abundance variations from North Atlantic Sites 552, 607, 658, 659 and 662: further evidence for marine plankton responding to orbital forcing. In Ruddiman, W.F., Sarnthein, M., et al., Proc. ODP, Sci. Results, 108: College Station, TX (Ocean Drilling Program), 121-141.

Cita, M.B., 1975a. The Miocene/Pliocene boundary: history and definition. In Saito, T., and Burckle, L.H., (Eds.), Late Neogene Epoch Boundaries. Spec. Publ. Micropaleontol., 1-30.

, 1975b. Studi sul Pliocene e gli strati di passaggoi dal Miocene al Pliocene, VII. Planktonic foraminiferal biozonation of the Mediterranean Pliocene deep sea record: a revision. Riv. Ital. Paleontol. Stratigr., 81:527-544.

Cita, M.B., and Gartner, S., 1973. Studi sul Pliocene e sugli strati al passaggio dal Miocene al Pliocene. IV. The stratotype Zanclean foraminiferal and nannofossil biostratigraphy. Riv. Ital. Paleontol. Stratigr., 79:503558.

Cita, M.B., Vergnaud-Grazzini, C., Robert, C., Chamley, H., Ciaranfi, N., and D'Onofrio, S., 1977. Paleoclimatic record of a long deep sea core from the eastern Mediterranean. Quat. Res., 8:205-235.

De Visser, J.P., Ebbing, J.H.J., Gudjonsson, L., Hilgen, F.J., Jorissen, F.J., Verhallen, P.J.J.M., and Zevenboom, D., 1989. The origin of rhythmic bedding in the Pliocene Trubi formation of Sicily, southern Italy. Palaeogeogr., Palaeoclimatol., Palaeoecol., 69:45-66.

Emeis, K.-C., Robertson, A.H.F., Richter, C., et al., 1996. Proc. ODP, Init. Repts., 160: College Station, TX (Ocean Drilling Program).

Eppley, R.W., 1989. New production: history, methods, problems. In Berger, W.H., Smetacek, V.S., and Wefer, G. (Eds.), Productivity of the Ocean: Present and Past. Dahlem Workshop Rep., 85-97.

Geitzenauer, K.R., Roche, M.B., and McIntyre, A., 1976. Modern Pacific coccolith assemblages: derivation and application to late Pleistocene paleotemperature analysis. In Cline, R.M., and Hays, J.D. (Eds.), Investigation of Late Quaternary Paleoceanography and Paleoclimatology. Mem.-Geol. Soc. Am., 145:423-448.

Hilgen, F.J., 1991a. Astronomical calibration of Gauss to Matuyama sapropels in the Mediterranean and implication for the geomagnetic polarity time scale. Earth Planet. Sci. Lett., 104:226-244.

, 1991b. Extension of the astronomically calibrated (polarity) time scale to the Miocene/Pliocene boundary. Earth Planet. Sci. Lett., 107:349-368.

Hilgen, F.J., and Langereis, C., 1993. A critical re-evaluation of the Miocene/ Pliocene boundary as defined in the Mediterranean. Earth Planet. Sci. Lett., 118:167-179.

Kidd, R.B., Cita, M.B., and Ryan, W.B.F., 1978. Stratigraphy of eastern Mediterranean sapropel sequences recovered during DSDP Leg 42A and their paleoenvironmental significance. In Hsü, K.J., Montadert, L., et al., Init. Repts. DSDP, 42 (Pt. 1): Washington (U.S. Govt. Printing Office), 421-443.

Legendre, L., and Le Fevre, J., 1989. Hydrodynamical singularities as controls of recycled versus export production in oceans. In Berger, W.H., Smetacek, V.S., and Wefer, G. (Eds.), Productivity of the Ocean: Present and Past: Chichester (John Wiley), 49-63.

Lourens, L.J., Antonarakou, A., Hilgen, F.J., Van Hoof, A.A.M., VergnaudGrazzini, C., and Zachariasse, W.J., 1996. Evaluation of the Plio-Pleistocene astronomical timescale. Paleoceanography, 11:391-413.

Lourens, L.J., Hilgen, F.J., Gudjonsson, L., and Zachariasse, W.J., 1992. Late Pliocene to early Pleistocene astronomically forced sea surface productivity and temperature variations in the Mediterranean. Mar. Micropaleontol., 19:49-78.

Martini, E., 1971. Standard Tertiary and Quaternary calcareous nannoplankton zonation. In Farinacci, A. (Ed.), Proc. 2nd Int. Conf. Planktonic Microfossils Roma: Rome (Ed. Tecnosci.), 2:739-785.

Matsuoka, H., and Okada, H., 1989. Quantitative analysis of Quaternary nannoplankton in the subtropical northwestern Pacific Ocean. Mar. Micropaleontol., 14:97-118.

McIntyre, A., and Bé, A.W.H., 1967. Modern coccolithophoridae of the Atlantic Ocean. I: placoliths and cyrtoliths. Deep-Sea Res. Part A, 17:561-597.

McIntyre, A., Bé, A.W.H., and Roche, M.B., 1970. Modern Pacific coccolithophorida: a paleontological thermometer. Trans. N.Y. Acad. Sci., 32:720-731.

Molfino, B., and McIntyre, A., 1990a. Nutricline variations in the equatorial Atlantic coincident with the Younger Dryas. Paleoceanography, 5:9971008 .

, 1990b. Precessional forcing of nutricline dynamics in the Equatorial Atlantic. Science, 249:766-769.

Muerdter, D.R., 1984. Low-salinity surface water incursions across the Strait of Sicily during late Quaternary sapropel intervals. Mar. Geol., 58:401414.

Müller, C., 1978. Neogene calcareous nannofossils from the Mediterranean-Leg 42A of the Deep Sea Drilling Project. In Hsü, K.J., Montadert, L., et al., Init. Repts DSDP, 42 (Pt. 1): Washington (U.S. Govt. Printing Office), 727-751.

1985. Late Miocene to Recent biostratigraphic and paleoenvironmental results from the Mediterranean based on calcareous nannoplankton. In Stanley, D.J., and Wezel, F.C. (Eds.), Geological Evolution of the Mediterranean Basin: New York (Springer-Verlag), 471-485.

Nijenhuis, I.A., Schenau, S.J., Van der Weijden, C.H., Hilgen, F.J., Lourens, L.J., and Zachariasse, W.J., 1996. On the origin of upper Miocene sapropelites: a case study from the Faneromeni section, Crete (Greece). Paleoceanography, 11:633-645.

Okada, H., and Bukry, D., 1980. Supplementary modification and introduction of code numbers to the low-latitude coccolith biostratigraphic zonation (Bukry, 1973; 1975). Mar. Micropaleontol., 5:321-325.

Olausson, E., 1961. Studies of deep-sea cores. Rep. Swed. Deep-Sea Exped., 1947-1948, 8:335-391.

Pedersen, T.F., and Calvert, S.E., 1990. Anoxia vs. productivity: what controls the formation of organic-carbon-rich sediments and sedimentary rocks? AAPG Bull., 74:454-466.

Perch-Nielsen, K., 1985. Cenozoic calcareous nannofossils. In Bolli, H.M., Saunders, J.B., and Perch-Nielsen, K. (Eds.), Plankton Stratigraphy: Cambridge (Cambridge Univ. Press), 427-554.

Raffi, I., and Flores, J.-A., 1995. Pleistocene through Miocene calcareous nannofossils from eastern equatorial Pacific Ocean (Leg 138). In Pisias, N.G., Mayer, L.A., Janecek, T.R., Palmer-Julson, A., and van Andel, T.H. (Eds.), Proc. ODP, Sci. Results, 138: College Station, TX (Ocean Drilling Program), 233-286.

Raffi, I., and Rio, D., 1979. Calcareous nannofossil biostratigraphy of DSDP Site 132-Leg 13 (Tyrrhenian Sea-Western Mediterranean). Riv. Ital. Paleontol. Stratigr., 85:127-172.

Rio, D., Raffi, I., and Villa, G., 1990. Pliocene-Pleistocene calcareous nannofossil distribution patterns in the Western Mediterranean. In Kastens, K.A., Mascle, J., et al., Proc. ODP, Sci. Results, 107: College Station, TX (Ocean Drilling Program), 513-533.

Rio, D., Sprovieri, R., and Raffi, I., 1984. Calcareous plankton biostratigraphy and biochronology of the Pliocene-lower Pleistocene succession of the Capo Rossello area, Sicily. Mar. Micropaleontol., 9:135-180. 
Rohling, E.J., 1991. A simple two-layered model for shoaling of the Eastern Mediterranean pycnocline due to glacio-eustatic sea level lowering. Paleoceanography, 6:537-541.

1994. Review and new aspects concerning the formation of eastern Mediterranean sapropels. Mar. Geol., 122:1-28.

Rohling, E.J., and Gieskes, W.W.C., 1989. Late Quaternary changes in Mediterranean intermediate water density and formation rate. Paleoceanography, 4:531-545.

Rohling, E.J., and Hilgen, F.J., 1991. The eastern Mediterranean climate at times of sapropel formation: a review. Geol. Mijnbouw, 70:253-264.

Rossignol-Strick, M., 1985. Mediterranean Quaternary sapropels, an immediate response of the African Monsoon to variation of insolation. Palaeogeogr., Palaeoclimatol., Palaeoecol., 49:237-263.

Ryan, W.B.F., 1972. Stratigraphy of late Quaternary sediments in the Eastern Mediterranean. In Stanley, D.J. (Ed.), The Mediterranean Sea: Stroudsburg, PA (Dowden, Hutchison and Ross), 149-169.

Sutherland, H.E., Calvert, S.E., and Morris, J.R., 1984. Geochemical studies of the recent sapropel and associated sediment from the Hellenic Outer Ridge, eastern Mediterranean Sea, I. Mineralogy and chemical composition. Mar. Geol., 56:79-92.

Thunell, R.C., 1979. Pliocene-Pleistocene paleotemperature and paleosalinity history of the Mediterranean Sea: results from Deep Sea Drilling Project Sites 125 and 132. Mar. Micropaleontol., 4:173-187.

Thunell, R., Rio, D., Sprovieri, R., and Raffi, I, 1991a. Limestone-marl couplets: origin of the Early Pliocene Trubi marls in Calabria, southern Italy. J. Sediment. Petrol., 61:1109-1122.
Thunell, R., Rio, D., Sprovieri, R., and Vergnaud-Grazzini, C., 1991b. An overview of the post-Messinian paleoenvironmental history of the Western Mediterranean. Paleoceanography, 6:143-164.

Thunell, R.C., and Williams, D.F., 1983. Paleotemperature and paleosalinity history of the eastern Mediterranean during the late Quaternary. Palaeogeogr., Palaeoclimatol., Palaeoecol., 44:23-39.

Thunell, R.C., Williams, D.F., and Kennett, J.P., 1977. Late Quaternary paleoclimatology, stratigraphy and sapropel history in Eastern Mediterranean deep-sea sediments. Mar. Micropaleontol., 2: 371-388.

Violanti, D., Grecchi, G., and Castradori, D., 1991. Paleoenvironmental interpretation of core Ban88-11GC (Eastern Mediterranean, PleistoceneHolocene) on the grounds of Foraminifera, Thecosomata and calcareous nannofossils. Il Quatern., 4:13-39.

Zijderveld, J.D.A., Hilgen, F.J., Langereis, C.G., Verhallen, P.J.J.M., and Zachariasse, W.J., 1991. Integrated magnetostratigraphy and biostratigraphy of the upper Pliocene-lower Pleistocene from the Monte Singa and Crotone areas in Calabria (Italy). Earth Planet. Sci. Lett., 107:697-714.

Date of initial receipt: 6 January 1997

Date of acceptance: 8 May 1997

Ms 160SR-005

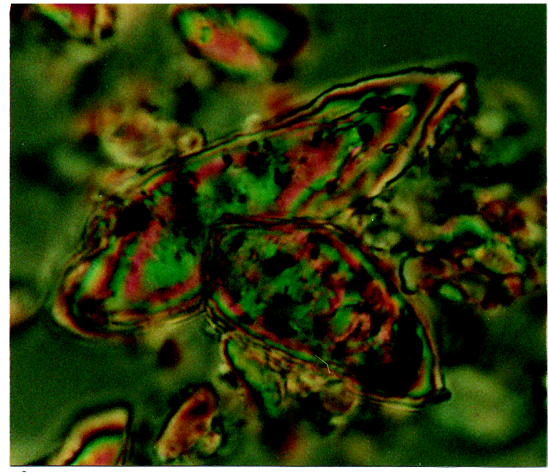

1

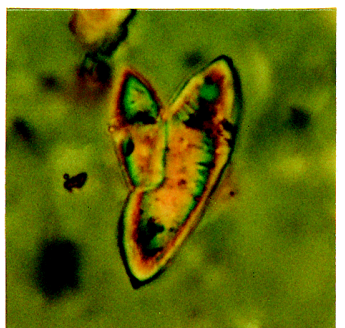

3

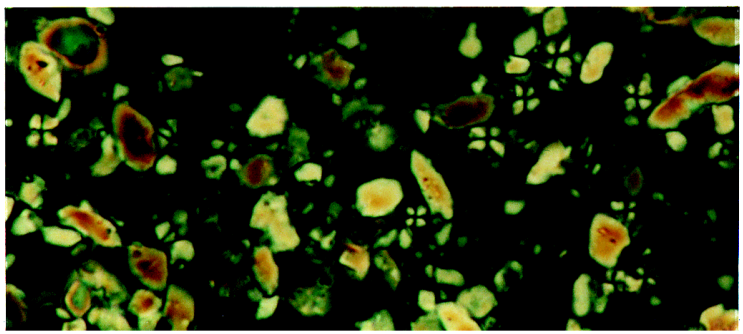

6

2

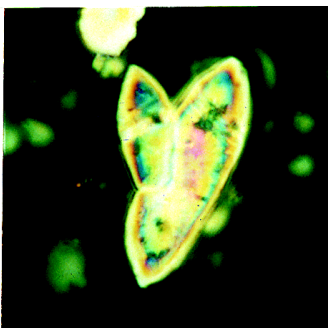

4

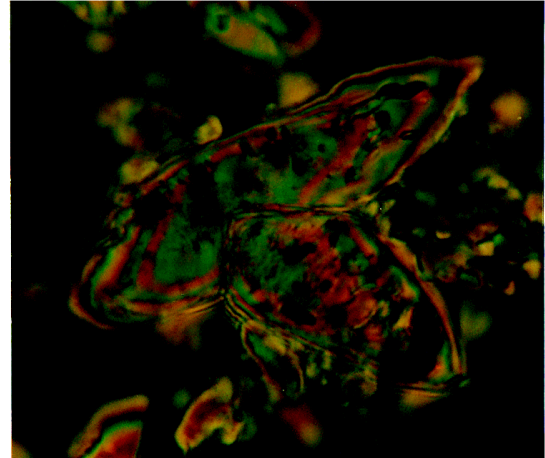

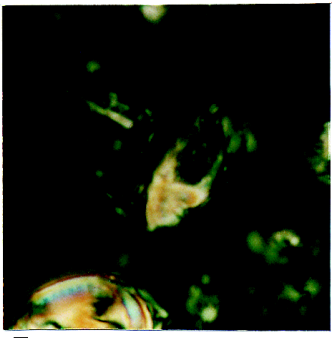

5

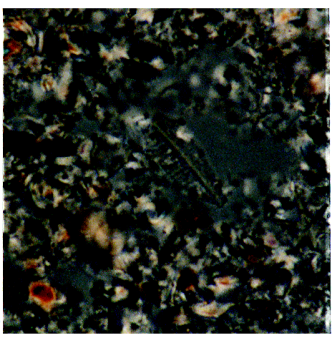

7

Plate 1. 1, 2. Large twin crystals of gypsum; 975×. Sample 160-967A-14X-1, $72-75 \mathrm{~cm}$; (1) parallel light; (2) crossed nicols. 3, 4. Twin crystals of gypsum; 975×. Sample 160-969B-11H-7, 40-42 cm; (3) parallel light; (4) crossed nicols. 5. Ceratolithus acutus Gartner and Bukry; 975×. Sample 160-969B-11H-6, 69$70 \mathrm{~cm}$; crossed nicols. 6. "Anomalous" abundance of Sphenolithus spp. (mostly S. gr. abies/moriformis); 975×. Sample 160-967A-14X-1, 54-57 cm; crossed nicols. 7. Triquetrorhabdulus rugosus Bramlette and Wilcoxon; 975×. Sample 160-969B-11H-5, 3-5 cm; parallel light. 

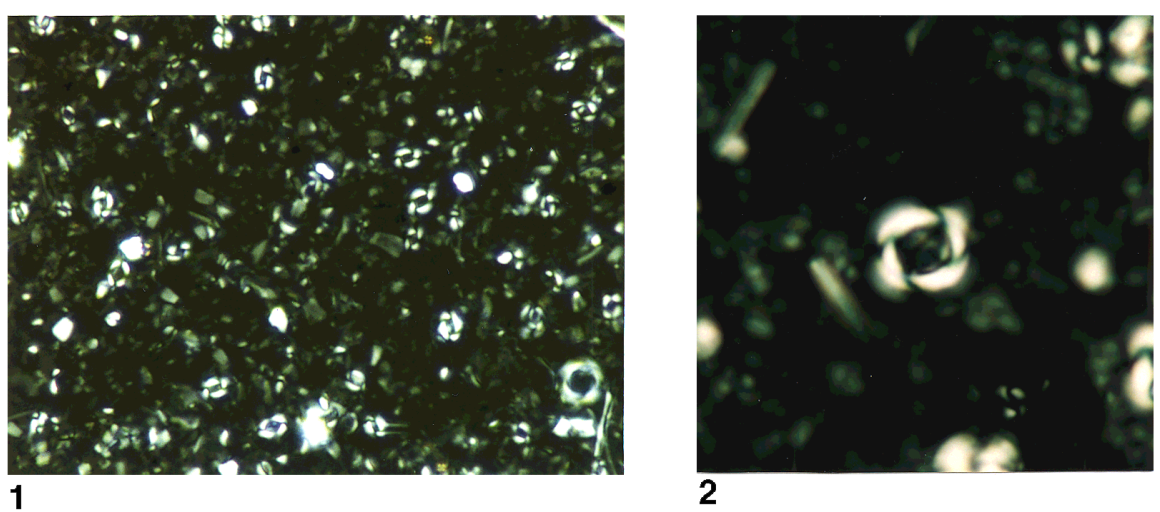

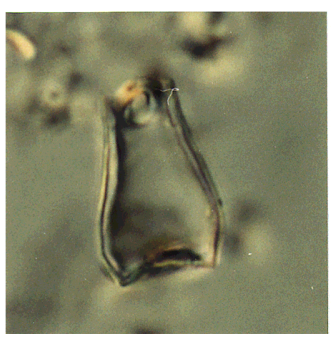

3

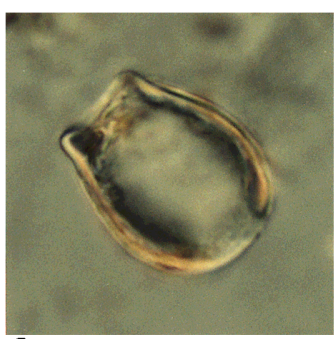

6

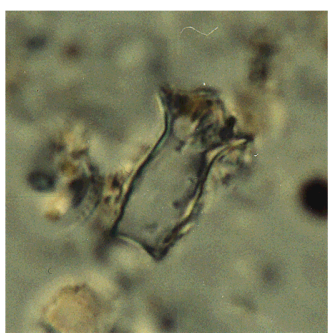

4

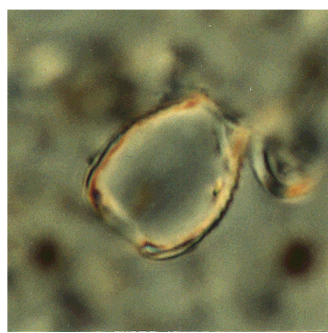

7

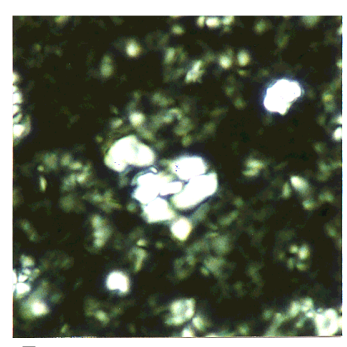

5

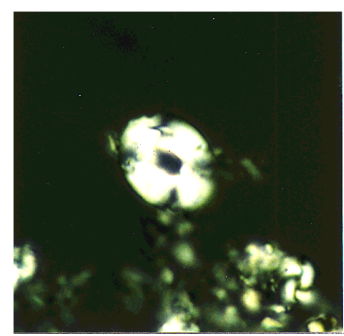

8

Plate 2. 1. Abundance of Florisphaera profunda Okada and Honjo (small, grey, polygonal calcite plates) in a sapropel layer; 975×. Sample 160-969B-11H-5, 91-93 cm; crossed nicols. 2. Reticulofenestra sp., with circular outline; 975×. Sample 160-969B-11H-6, 19-20 cm; crossed nicols. 3-7. Different morphotypes of Scyphosphaera spp.; all 975×. Sample 160-969B-11H-6, 124-126 cm; parallel light. 5. Helicosphaera intermedia Martini; 975×. Sample 160-969B-11H-5, 91-93 cm; crossed nicols. 8. Reticulofenestra pseudoumbilicus Gartner; 975×. Sample 160-969B-11H-5, 3-5 cm; crossed nicols. 